\title{
Occurrence of Gas Hydrate in Oligocene Frio Sand: Alaminos Canyon Block 818: Northern Gulf of Mexico
}

\author{
Ray Boswell a, ${ }^{*}$, Dianna Shelander b, Myung Lee c, Tom Latham d, Tim Collett c, \\ Gilles Guerin e, George Moridis f, Matthew Reagan f, Dave Goldberg e \\ a U.S. Department of Energy, National Energy Technology Laboratory, 3610 Collins Ferry Road, \\ Morgantown, WV 26507, USA \\ b Schlumberger Reservoir Seismic Services, Houston, TX, USA \\ c U.S. Geological Survey, Denver, CO, USA \\ d Chevron North America Exploration and Production Company, Houston, TX, USA \\ e Lamont-Doherty Earth Observatory, Columbia University, New York, NY, USA \\ f Lawrence Berkeley National Laboratory, Berkeley, CA, USA
}

Keywords: gas hydrate, Gulf of Mexico, Alaminos Canyon, Frio sand

\begin{abstract}
A unique set of high-quality downhole shallow subsurface well log data combined with industry standard 3D seismic data from the Alaminos Canyon area has enabled the first detailed description of a concentrated gas hydrate accumulation within sand in the Gulf of Mexico. The gas hydrate occurs within very fine grained, immature volcaniclastic sands of the Oligocene Frio sand. Analysis of well data acquired from the Alaminos Canyon Block 818 \#1 ("Tigershark") well shows a total gas hydrate occurrence $13 \mathrm{~m}$ thick, with inferred gas hydrate saturation as high as $80 \%$ of sediment pore space. Average porosity in the reservoir is estimated from log data at approximately $42 \%$. Permeability in the absence of gas hydrates, as revealed from the analysis of core samples retrieved from the well, ranges from 600 to 1500 millidarcies. The 3-D seismic data reveals a strong reflector consistent with significant increase in acoustic velocities that correlates with the top of the gas-hydrate-bearing sand. This reflector extends across an area of approximately $0.8 \mathrm{~km}^{2}$ and delineates the minimal probable extent of the gas hydrate accumulation. The base of the inferred gas-hydrate zone also correlates well with a very strong seismic reflector that indicates transition into units of significantly reduced acoustic velocity. Seismic inversion analyses indicate uniformly high gas-hydrate saturations throughout the region where the Frio sand exists within the gas hydrate stability zone. Numerical modeling of the potential production of natural gas from the interpreted accumulation indicates serious challenges for depressurization-based production in settings with strong potential pressure support from extensive underlying aquifers.
\end{abstract}

\section{Introduction}

The term "gas hydrate" is commonly used to describe clathrate compounds of water and various appropriately-sized gas molecules, most commonly methane. Gas hydrates form naturally in sediments given suitable temperature and pressure and sufficient supplies of both water and gases. The macroscopic form in which gas hydrate occurs varies considerably, including large massive mounds at the seafloor, as nodules, veins and fracture fillings; and as disseminated pore-filling grains in more deeply buried sediments. Gas hydrate occurrences are generally restricted to the upper several hundred meters of marine sediments under deep continental shelves and slopes and to areas in the Arctic, where the temperature regime is conditioned by the presence of permafrost. The recognition of widespread and large-scale occurrences of gas hydrate in marine

environments has raised many fundamental scientific and public interest concerns. In particular, marine gas hydrate-bearing sediments have potential as a future energy source, are a suspected hazard to oil and gas drilling operations, and have potentially significant implications for global environmental processes such as climate change and the carbon cycling (Kvenvolden, 2000).

In comparison to accumulations encased in unconsolidated and impermeable shallow marine muds, gas hydrate reservoirs in porous and permeable sands are the most promising targets for potential natural gas production (Moridis and Reagan, 2007a,b; Moridis and Sloan, 2007) they provide: 1) the means to transport pressure or temperature perturbations into a gas-hydrate-bearing formation 


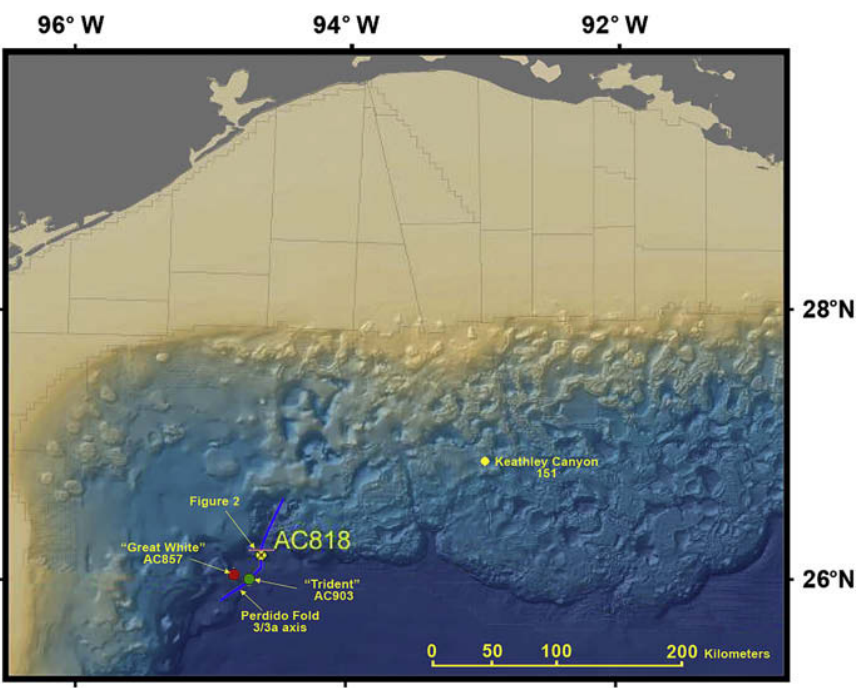

Fig. 1. Location of wells and seismic data cited in the text within the Northern Gulf of Mexico. Background image is a color-coded topographic map of the seafloor with darker water being denoted by darker blue colors. (For interpretation of the references to colour in this figure legend, the reader is referred to the web version of this article.)

efficiently, and 2) an avenue for released gas to be gathered at the well. Among these potential sand reservoirs, the most promising will be those, like the accumulation described in this paper, that lie at depths close to the base of gas hydrate stability (BGHS).

This paper provides the first description of inferred gas hydrates within sand reservoirs in the Gulf of Mexico. Previous accounts of gas hydrate bearing marine sand reservoirs worldwide come from the Nankai trough of Japan (Fujii et al., 2005) and from the northeast Pacific, off the coast of Vancouver Island (Reidel et al., 2006).

\subsection{Gas hydrates in the Gulf of Mexico}

Naturally-occurring gas hydrates are well documented throughout the Gulf of Mexico (Milkov and Sassen, 2001). However, most previous investigations have relied upon either direct observation of surficial features and processes or examination of shallow (less than $5 \mathrm{~m}$ ) piston cores. As a result, most descriptions of gas hydrate in the Gulf of Mexico relate to massive gas hydrate accumulations exposed on the seafloor in association with known or inferred hydrocarbon vents and seeps (Roberts and Carney, 1997; MacDonald et al., 1994). In general, the potential for occurrence of significant subsurface pore-filling gas hydrates was perceived as likely very limited due to both the lack of documented geophysical indicators for gas hydrate such as regional bottom-simulating reflectors (Kvenvolden and Lorenson, 2001; Cooper and Hart, 2003) and the region's elevated heat flow and salinity (Paull et al., 2005; Ruppel et al., 2005). Nonetheless, McConnell and Kendall (2002) showed seismic data from the Walker Ridge area and noted a series of aligned terminations of free gas accumulations that provided an alternative to the continuous bottom-simulating reflector (BSR) as an indicator of the likely position of the base of gas hydrate stability (BGHS; as noted previously by Vanneste et al., 2001). Subsequently, closer examination of seismic data across the Gulf of Mexico reveals the presence of continuous BSRs in other locations, including Keathley Canyon Block 151 (Hutchinson et al., in press-a, 2008) and Green Canyon (Smith et al., 2005).

In 2005, the Gulf of Mexico Gas Hydrates Joint Industry Project (the JIP) selected two locations in the northern Gulf of Mexico to conduct drilling, logging, and coring in gas-hydrate-bearing formations (Ruppel et al., 2008). At the site in Keathley Canyon Block 151 where earlier work had identified a subtle BSR, a zone of fracture-controlled gas hydrate occurrence within silts and muds was discovered at a depth range from 220 to $300 \mathrm{~m}$ below the seafloor (Cook et al., 2008; Lee and Collett, 2008). The Keathley Canyon accumulation was well above the level of the BSR; however the occurrence of the deposit was found to be in close accordance with pre-drill estimates of gas hydrate occurrence based on seismic inversion (Dai et al., 2008). The second site, in Atwater Valley Blocks 13 and 14, featured seafloor mounds and shallow-focused flow features (Hart et al., 2008; Wood et al., 2008). Gas hydrate in the Atwater Valley drilling was limited and restricted to very shallow depths (Claypool, 2006).

\subsection{Geologic setting: Alaminos Canyon Block 818}

The Alaminos Canyon (AC) protraction area is located in the deepwater of the western Gulf of Mexico (Fig. 1). The dominant geologic structures in the area are a series of northeast-southwest trending salt-cored box folds of the Perdido fold belt. Over most of the AC area, these folds lie beneath a thick and mobile salt canopy (Trudgill et al., 1999). The region is known for oil and gas seeps, most notably in block AC 645 (e.g., Cordes et al., 2007). Investigations

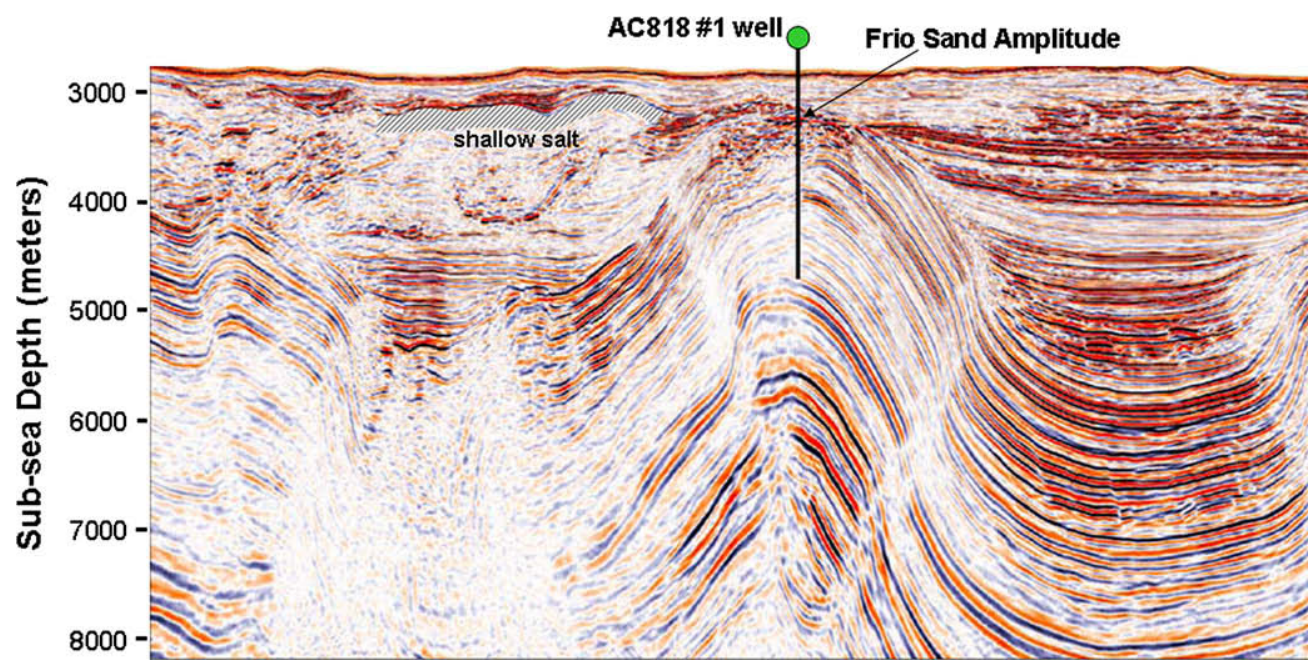

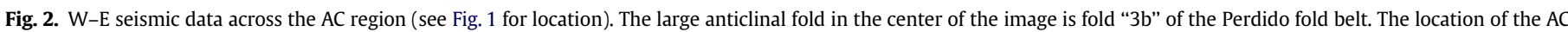

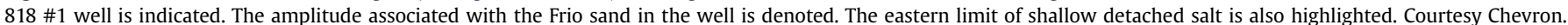


during 2006 (Roberts et al., 2007) using the submersible Alvin have observed chemosynthetic communities and other indicators of significant hydrocarbon flux within AC818.

In March, 2004, the "Tigershark" exploration well was drilled in 9004 feet $(2744 \mathrm{~m})$ of water in AC block 818. The well was located along the crest of fold " $3 \mathrm{~b}$ " within the Perdido fold belt (see Fiduk et al., 1999; Trudgill et al., 1999) to test an emerging deepwater Lower Tertiary turbidite oil and gas play (Meyer et al., 2005). The well discovered $\sim 60 \mathrm{ft}(18 \mathrm{~m})$ of oil in the Paleocene Wilcox Formation, and along with other discoveries (including the "Trident" (AC block 903) and "Great White" (AC block 857) wells) confirmed the presence of a fully functioning petroleum system in the region.

The youngest and shallowest proven oil and gas reservoirs within the Lower Tertiary deepwater turbidite play are the Oligocene Frio sands. Although the Frio sands are typically well below the BGHS throughout most of the Gulf of Mexico, the significant uplift of the Perdido fold belt has raised the unit to unusually shallow depths over fold 3b (Fig. 2) and produced a four-way structural closure in the northeastern corner of AC 818 (Fig. 3).

Analysis of percussion sidewall core samples taken from the AC block $818 \# 1$ well indicate that the Frio sand occurs as a very finegrained (40-60 micron) volcanoclastic sand (Fig. 4). A notable feature of the unit, which is thought to be typical of the Frio sand in the region, is the abundance of angular volcanic glass shards and feldspathic rock fragments that result in elevated natural radioactivity as compared to more typical quartzose sands, making the formation appear much more clay-rich in gamma-ray log data than they actually are.

We consider petrophysical data obtained from the sidewall core plugs to be problematic due to the potential for grain compaction during sample collection (see Shafer et al., 2005), particularly given the highly unconsolidated, high-porosity, volcanoclastic fabric of the Frio sand. Nonetheless, the data do provide an indication of reservoir quality. The reported porosity, as determined from the summation of volumes of all fluids extracted through retort, ranges

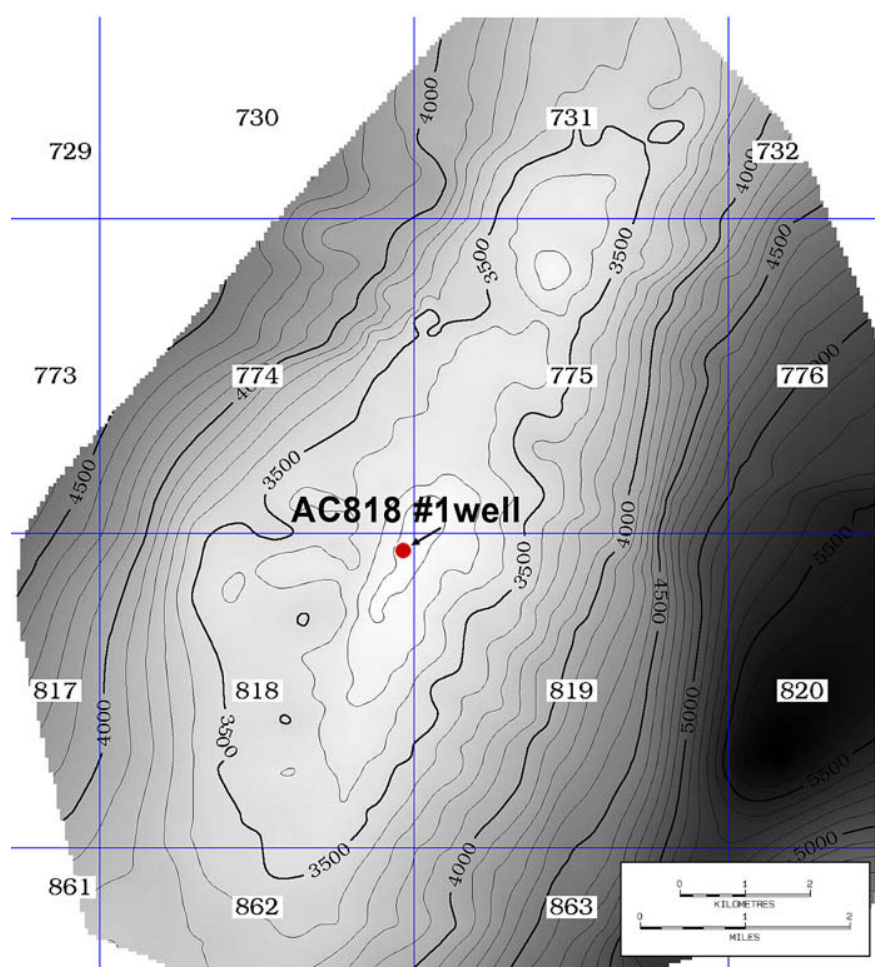

Fig. 3. Structural contours on the base of the Plio-Pleistocene shale section that overlies the Frio sand showing four-way closure that forms the trap for the AC818 gas hydrate accumulation. Contour interval is $100 \mathrm{~m}$.

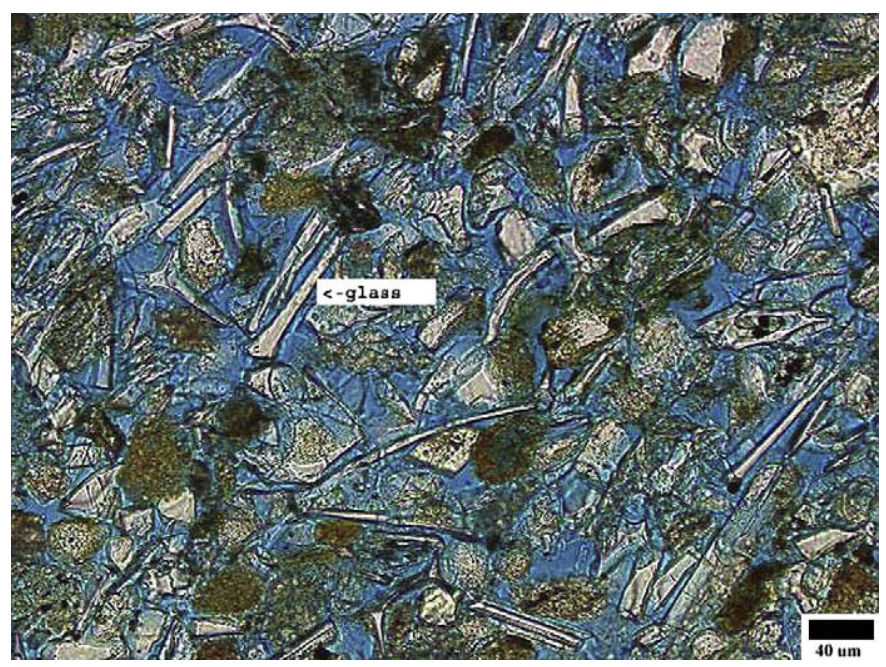

Fig. 4. Thin-section photomicrograph of portion of a sidewall core recovered from the gas hydrate bearing portion of the Frio sands in the AC 818 \#1 well. Blue is porosity. The elongated light-colored grains are shards of volcanic glass. Dark grains are shalerich rock fragments. Courtesy Chevron.

from $28 \%$ to nearly $34 \%$. These values are roughly $10 \%$ less than that as determined from the density log as discussion below. Estimated matrix permeability, as determined from algorithms based on measured porosity, grain sizes, and other data, ranges from 550 to 1500 millidarcies (Table 1).

\subsection{Acquisition and uniqueness of the AC818 data set}

The AC818 log data were acquired to investigate the nature of the sediments associated with a strong seismic reflector interpreted to occur roughly $1500 \mathrm{ft}$ (roughly $460 \mathrm{~m}$ ) below the seafloor. This depth coincides closely with the expected depth of both the Oligocene Frio sands (a secondary regional oil and gas reservoir) and the BGHS. Drilling parameters were tightly controlled to prevent the turbulent flow of drilling fluids and enlargement of the borehole due to sediment removal. Surface casing was set at an unusually shallow depth to enable well log data acquisition throughout this interval in open hole. Acquiring these shallow logs marked a major deviation from the standard industry practice of rapidly drilling and casing large boreholes through the gas hydrate stability zone (GHSZ) to ensure wellbore stability and drilling safety. As a result, the AC818 $\log$ data represents the first known suite of high-quality well logs obtained from within the gas hydrate stability zone in the deepwater Gulf of Mexico (see Smith et al., 2006).

The Frio sand was encountered as expected at a drilling depth $10537 \mathrm{ft}(3212 \mathrm{~m})^{1}$, at which time a return flow of 246 barrels (bbl) drilling fluid was observed. In response, drilling fluid weight was increased from 8.7 to 9.1 pounds per gallon (ppg). Indications of gas flow also coincided with the penetration of the Frio sand: mud log data from above the Frio sand indicated low levels of methane gas (less than $1 \%$ gas in air), but once drilling proceeded into the Frio sand, mudlog gas content increased to $10-20 \%$ concentrations. These gas levels persisted to $10580 \mathrm{ft}(3225 \mathrm{~m})$. Below this depth, gas content decreased to about $\sim 5 \%$ and continued to decrease to $\sim 2 \%$ at the interpreted base of the Frio sand at $10840 \mathrm{ft}(3304 \mathrm{~m})$. Gas content then decreased to levels of $1 \%$ or less.

${ }^{1}$ Depths are reported in the text and figures as drilling depth measured relative to the drill rig floor, which was located 92 feet above sea-level. Given the water depth of $9004 \mathrm{ft}$., subsurface depths equate to reported drilling depth minus $9096 \mathrm{ft}$. 
Table 1

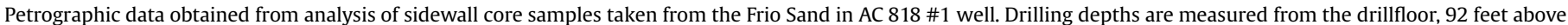
sea level. Depths noted in figures and text are drilling depths.

\begin{tabular}{|c|c|c|c|c|c|}
\hline Drilling Depth (ft) & Depth below Seafloor (ft) & Permeability (mD) & Porosity (\%) & Crit. Wat. Sat (Swc \%) & Description \\
\hline 10489 & 1393 & - & - & - & Shale, dark grey \\
\hline 10532 & 1436 & 1050 & 30.1 & 35 & Sand, fine- to very fine-grained \\
\hline 10535 & 1439 & 830 & 29.1 & 36 & Sand, very fine-grained \\
\hline 10538 & 1442 & 1000 & 31.1 & 36 & Sand, very fine-grained \\
\hline 10541 & 1445 & 950 & 30.2 & 35 & Sand, very fine-grained \\
\hline 10544 & 1448 & 900 & 29.7 & 36 & Sand, very fine-grained \\
\hline 10547 & 1451 & 1100 & 30.7 & 36 & Sand, very fine-grained \\
\hline 10550 & 1454 & 475 & 27.5 & 38 & Sand, very fine-grained \\
\hline 10556 & 1460 & - & - & - & Silt \\
\hline 10559 & 1463 & 625 & 28.1 & 37 & Sand, very fine-grained \\
\hline 10562 & 1466 & 880 & 30.5 & 36 & Sand, very fine-grained \\
\hline 10565 & 1469 & 1500 & 32.3 & 36 & Sand, fine- to very fine-grained \\
\hline 10568 & 1472 & 765 & 30.6 & 38 & Sand, very fine-grained \\
\hline 10571 & 1475 & 750 & 30.1 & 37 & Sand, very fine-grained \\
\hline 10574 & 1478 & 690 & 30.3 & 37 & Sand, very fine-grained \\
\hline 10580 & 1484 & 1150 & 33.4 & 38 & Sand, very fine-grained \\
\hline 10583 & 1487 & 1300 & 32.9 & 38 & Sand, very fine-grained \\
\hline 10586 & 1490 & 990 & 33.7 & 39 & Sand, very fine-grained \\
\hline 10592 & 1496 & 930 & 31.4 & 37 & Sand, fine- to very-fine grained \\
\hline 10596 & 1500 & 910 & 30.7 & 37 & Sand, fine- to very-fine grained \\
\hline 10609 & 1513 & 550 & 31.3 & 39 & Sand, very fine-grained \\
\hline 10614 & 1518 & 595 & 31.6 & 40 & Sand, very fine-grained \\
\hline
\end{tabular}

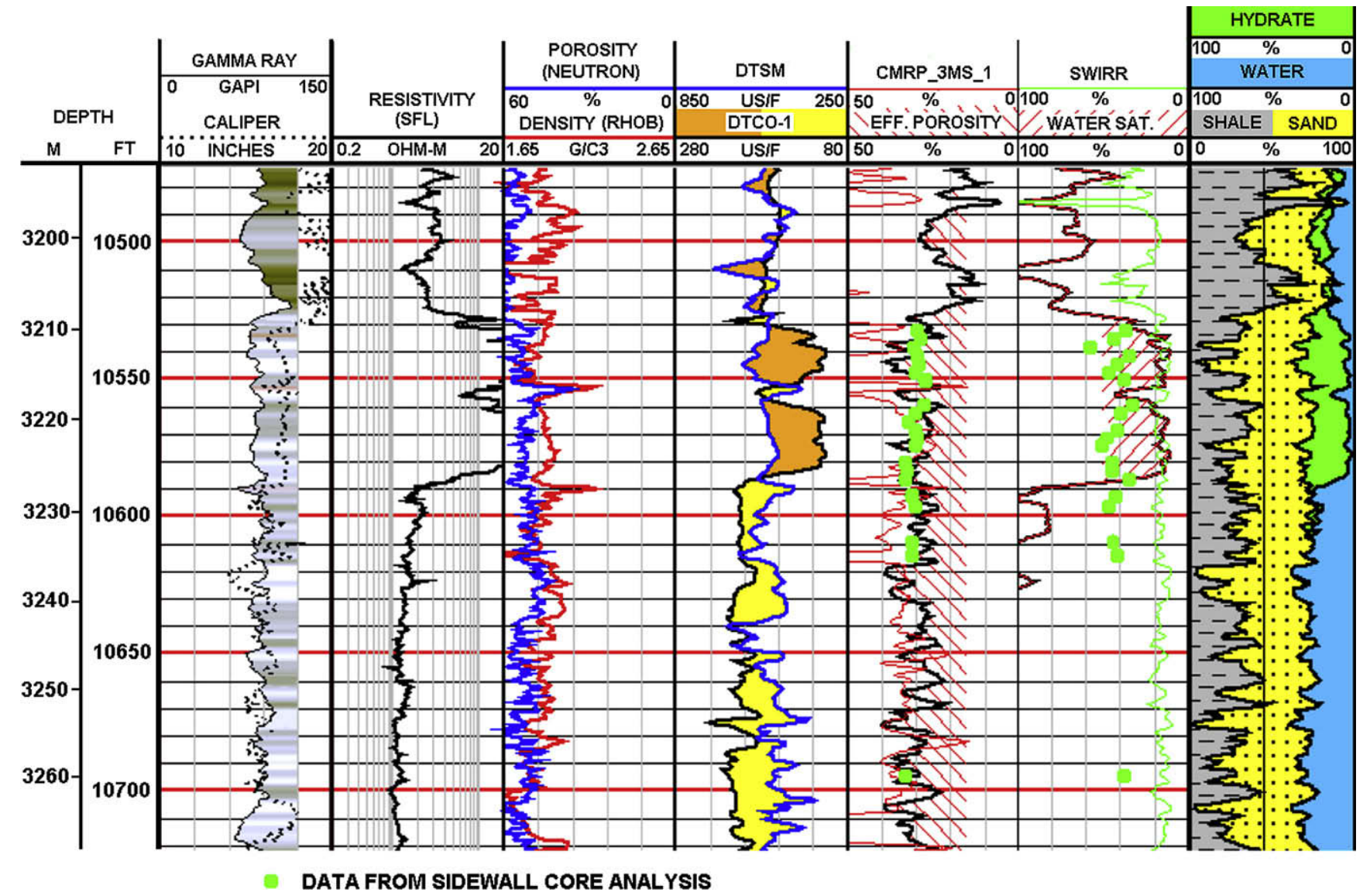

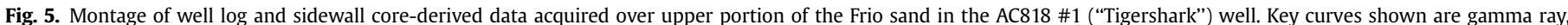

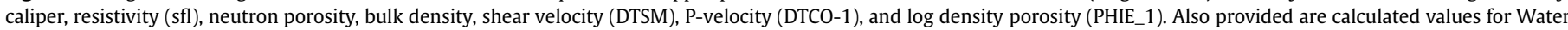

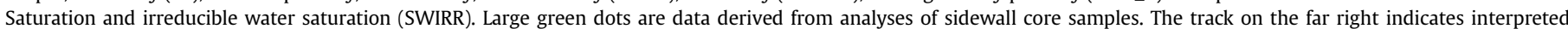

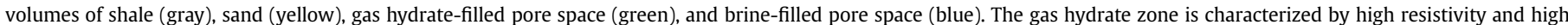

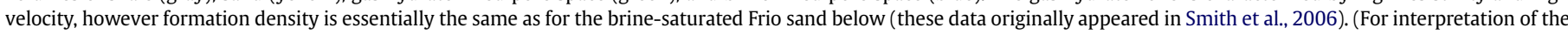
references to colour in this figure legend, the reader is referred to the web version of this article.) 

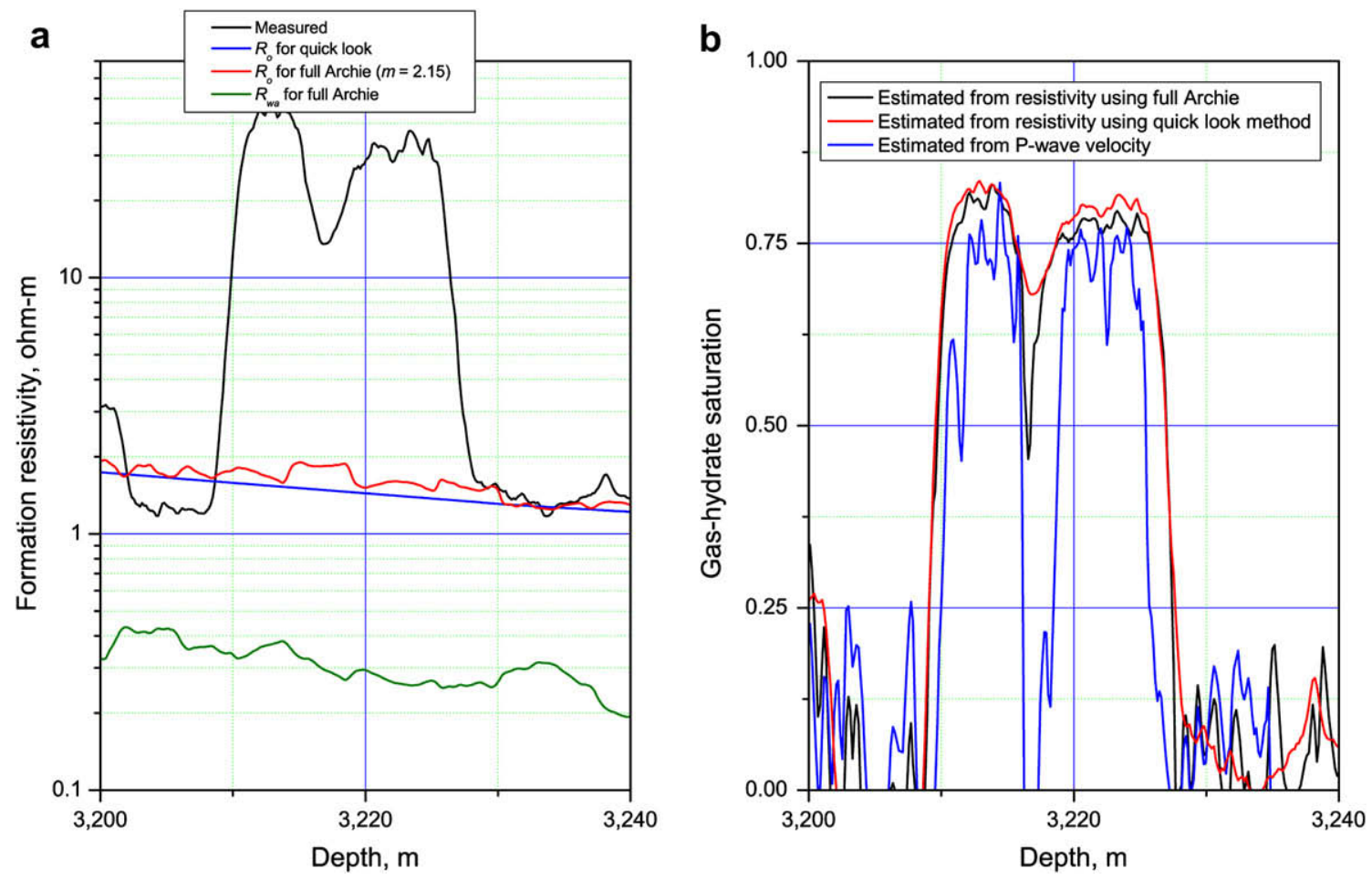

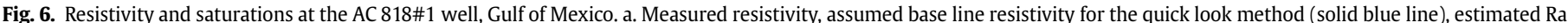

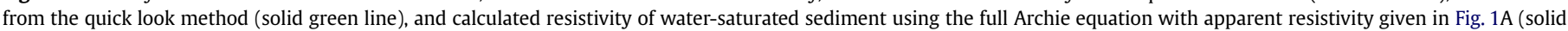

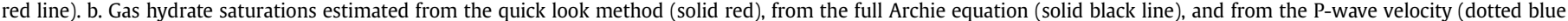
line). (For interpretation of the references to colour in this figure legend, the reader is referred to the web version of this article.)
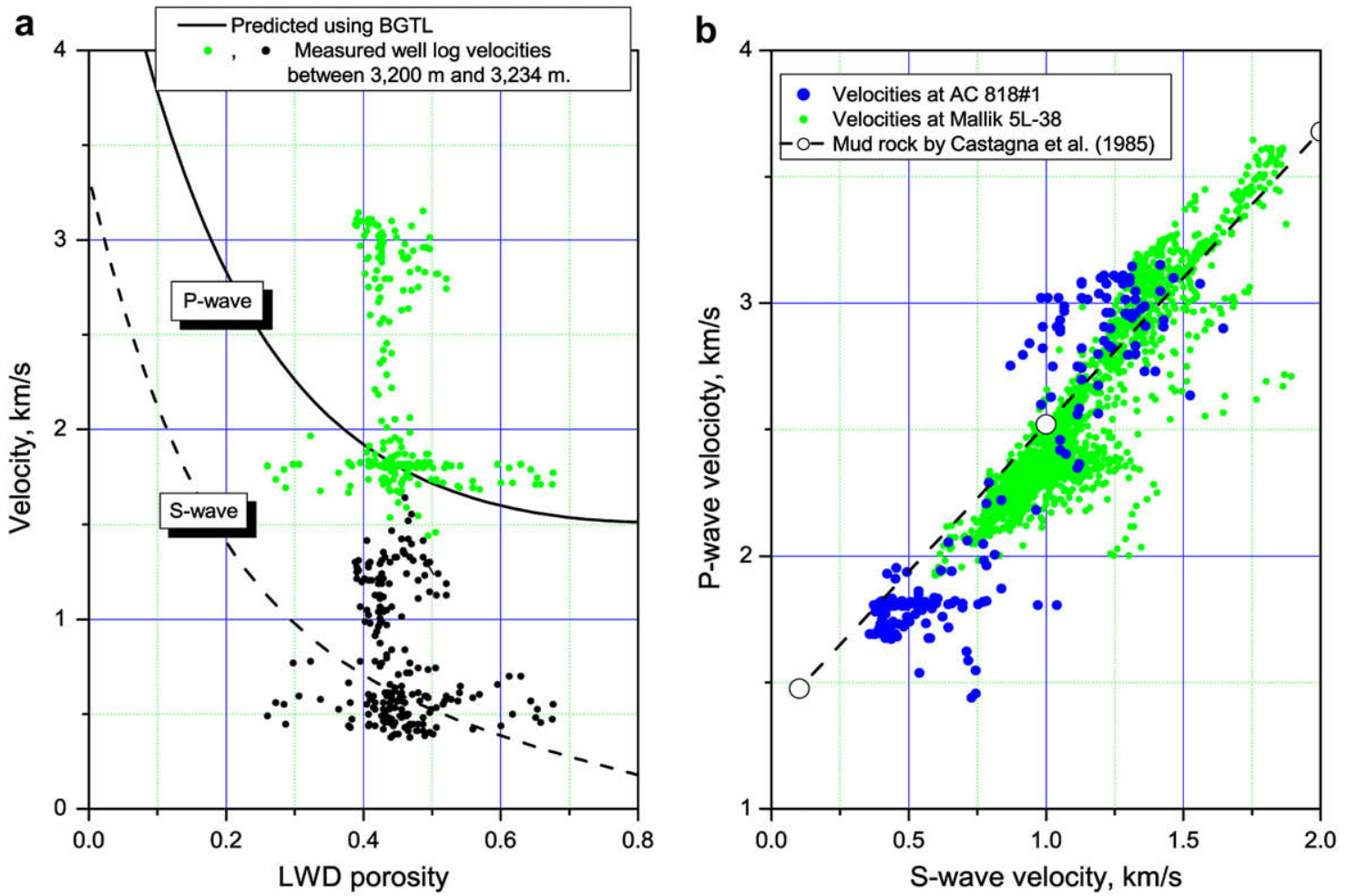

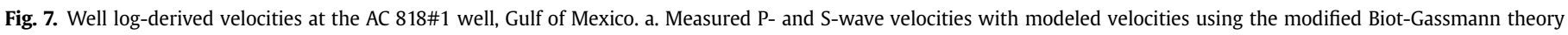
(BGTL). b. Relationship between P- and S-wave velocities. 


\section{Log data interpretation}

Log data indicate that the onset and initial decline of gas influx as observed in the mud log data corresponds closely to elevated formation resistivity and sonic velocity as seen in the log data. A composite display of well log and other data obtained from the AC818 \#1 well is provided in Fig. 5. The following description of the reservoir is based on an integrated analysis of the gamma ray, resistivity, and bulk density data, as well as re-processing and analysis of the sonic log data.

\subsection{Formation porosity}

Analysis of the density log suite assuming a constant grain density of $2.65 \mathrm{~g} / \mathrm{cm}^{3}$ (typical for terrigenous sand reservoirs) would indicate an average porosity of $47 \%$ for the high-resistivity interval of $\sim 47 \%$. However, to account for the unknown percentage of lower-density grains within the matrix, we assume that volcanic glass (with density of 2.35-2.45 g/ $\mathrm{cm}^{3}$; Shipley and Sarna-Wojcicki, 1982) comprises approximately $50 \%$ of the rock volume, resulting in an average grain density of $2.525 \mathrm{~g} / \mathrm{cm}^{3}$. Using this value, the porosity within the upper $15 \mathrm{~m}$ of the Frio sands as determined from the density log is roughly $42 \%$. This value is $10-12 \%$ greater than that reported from sidewall core analyses (Table 1). However, rock physics modeling using the modified Biot-Gassman theory of Lee (2002, 2005; hereafter referred to as the BGTL) fails to accurately match well log observed P- and S-wave velocities and estimated gas hydrate saturations when the corederived porosities are used. In contrast, using the higher log-derived porosities provided a much closer match of observed values, and is therefore the preferred estimate of the in situ formation porosity.

\subsection{Gas hydrate saturation estimated from resistivity data}

A primary tool for the determination of gas hydrate saturation is analysis of the formation resistivity. The formation resistivity of gas hydrate-bearing sediment (GHBS), $R_{t}$, is given by

$$
R_{t}=\frac{a R_{w}}{\phi^{m} S_{w}^{n}}
$$

where $a$ and $n$ are constants, $R_{w}$ is the resistivity of connate water, $m$ is the cementation factor, $\phi$ is the porosity, and $S_{w}$ is the water saturation. The saturation of gas hydrate $\left(S_{g h}\right)$ can be estimated from the resistivity using the following equation (Collett and Ladd, 2000) with $n=1.9386$ :

$S=1-\left(\frac{a R_{w}}{\phi^{m} R_{t}}\right)^{1 / n}$

When $R_{w}$ is available, fluid saturations can be estimated from equation (2) given estimates of Archie parameters $a$ and $m$. When $R_{w}$ is not available, a "quick look" method (Collett and Ladd, 2000) can be applied to estimate saturations and apparent resistivity $R_{a}$ $\left(R_{a}=a R_{w}\right)$. Comparison of measured resistivity to estimates of baseline resistivity (expected resistivity given 100\% saturation with connate water) using both the quick look and full Archie methods is provided as Fig. 6a. Gas hydrate saturation (Sgh) is determined (Fig. 6b) by comparing measured resistivity to the baseline estimate and attributing the full difference to the presence of gas hydrate. Calculations using both the quick look and full Archie approaches indicate Sgh greater than 70\% over an interval from 10 530 to $10585 \mathrm{ft}$ (3210-3226 m) with maximum Sgh in excess of $80 \%$.

\subsection{Gas hydrate saturation estimated from sonic log data}

We have also estimated gas hydrate saturation by comparing reprocessed sonic log data to predicted velocities for water-saturated sediments using the BGTL (Fig. 6a). Fig. 7a shows measured P-wave (green dots) and S-wave (black dots) velocities as a function of log-derived porosity. On the basis of Fig. 7a, the BGTL parameter $m=1.8$ is determined to be appropriate for modeling velocities for this deposit. As with the resistivity calculation, the associated
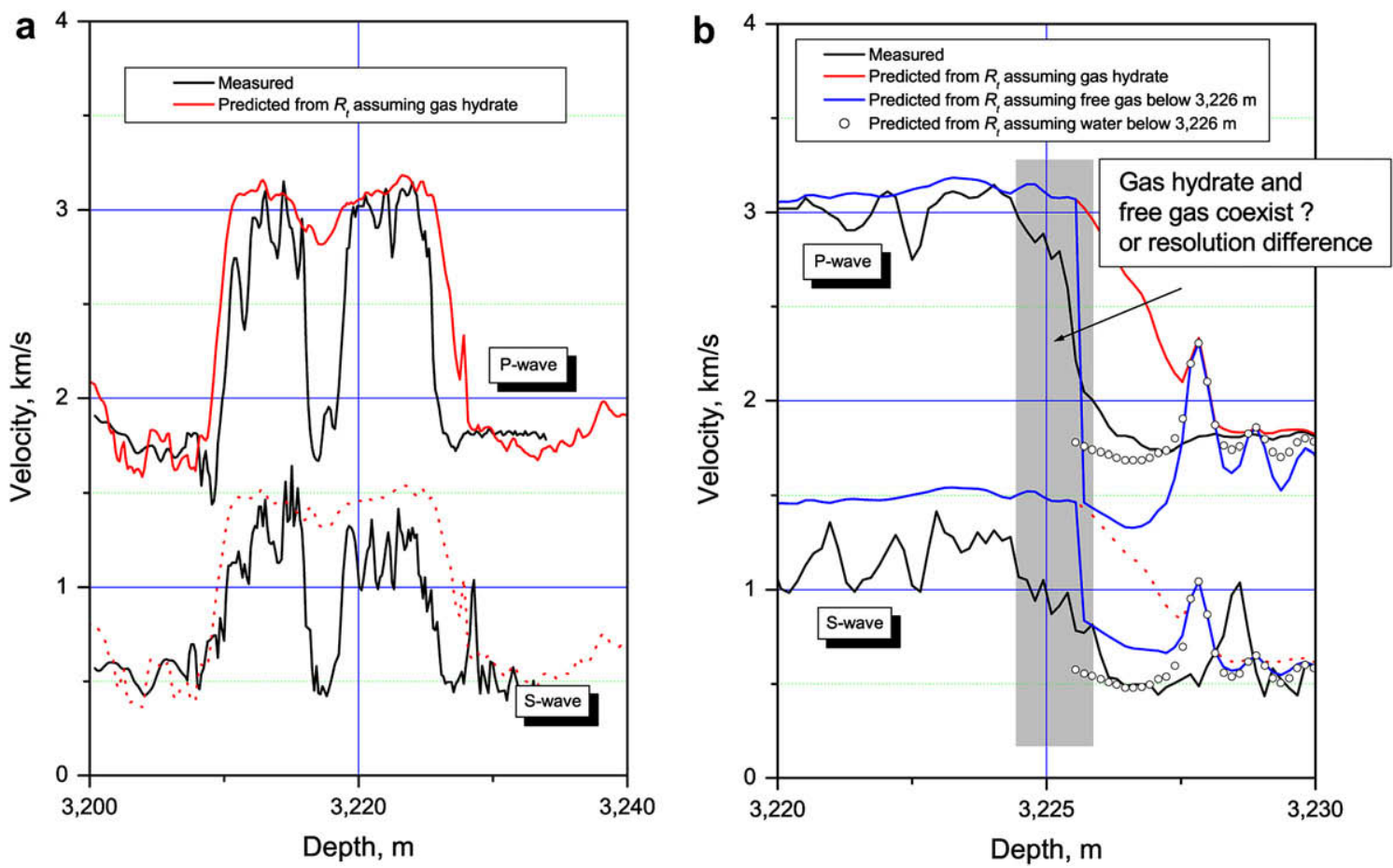

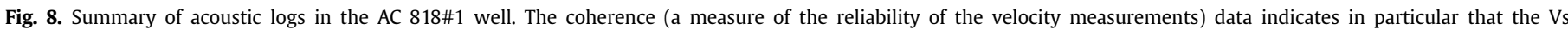

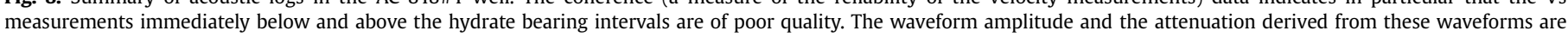
indicative of the dissipative influence of high gas hydrate concentration. 


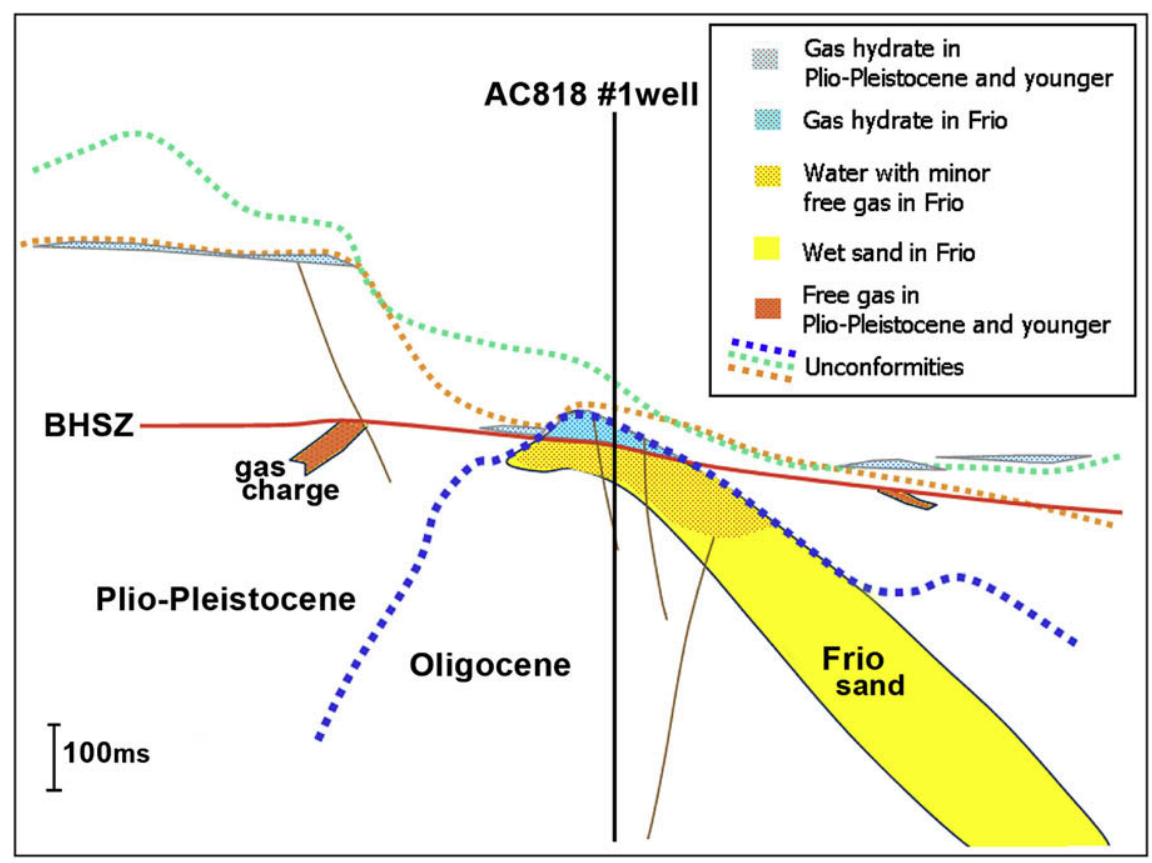

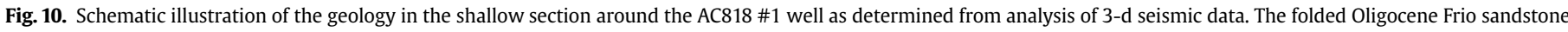

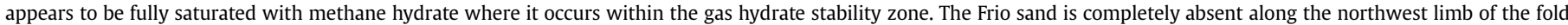

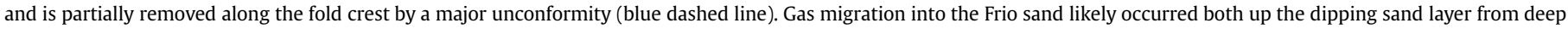

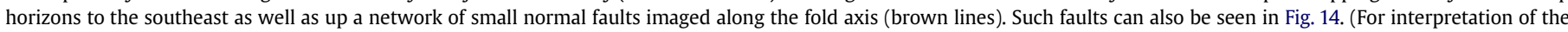
references to colour in this figure legend, the reader is referred to the web version of this article.)

calculated from resistivity in this zone and also at a similar zone near $10525 \mathrm{ft}(3208 \mathrm{~m})$. We attribute these differences to the lower vertical resolution of the resistivity tool, and consequently, the total thickness of the hydrate-bearing interval is interpreted to be better represented by the sonic data. However, detecting the presence of free gas in low saturations from the sonic log is difficult because the measured velocities may be close to those of water-saturated sediments. Therefore, from these data, we cannot confidently determine whether free gas is present below the hydrate-bearing sediments.

\subsection{Acoustic waveforms and attenuation}

Despite good hole conditions, the acoustic waveforms recorded during the two passes with the dipole sonic imager (DSI) logging tool were noisy in a number of intervals and required re-processing in order to improve the quality of the $\mathrm{Vp}$ and Vs data. The reprocessed Vp and Vs logs show higher acoustic velocity than the original data over the two intervals where high concentrations of gas hydrate are believed to be present. Nonetheless, despite the re-processing of the dipole waveforms, the low coherence measured across the receiver array (Fig. 9) indicates poor reliability (weak and noisy signal) for the Vs data below $10580 \mathrm{ft}(3213 \mathrm{~m}$ ). A likely reason for the low coherence of the dipole waveforms in these poorly consolidated sediments is the high frequency of the dipole source used (centered on $\sim 4 \mathrm{kHz}$ ). A lower frequency pulse $(<1 \mathrm{kHz})$ would have likely produced better data.

Following the method described by Guerin and Goldberg (2002), we calculated the attenuation of the recorded monopole and dipole acoustic waveforms. The low amplitude of the P-wave arrival observed in the monopole waveforms in the two hydratebearing intervals can be associated with a clear increase in compressional attenuation in these intervals, as measured on two receivers of the DSI array (Fig. 9). The attenuation calculated from the dipole waveforms also shows higher values in the upper gas hydrate-bearing zone, but the correlation between gas hydrate occurrence and attenuation in the deeper interval is not as clear as in the monopole data, a likely consequence of the noisy nature of the dipole waveforms.

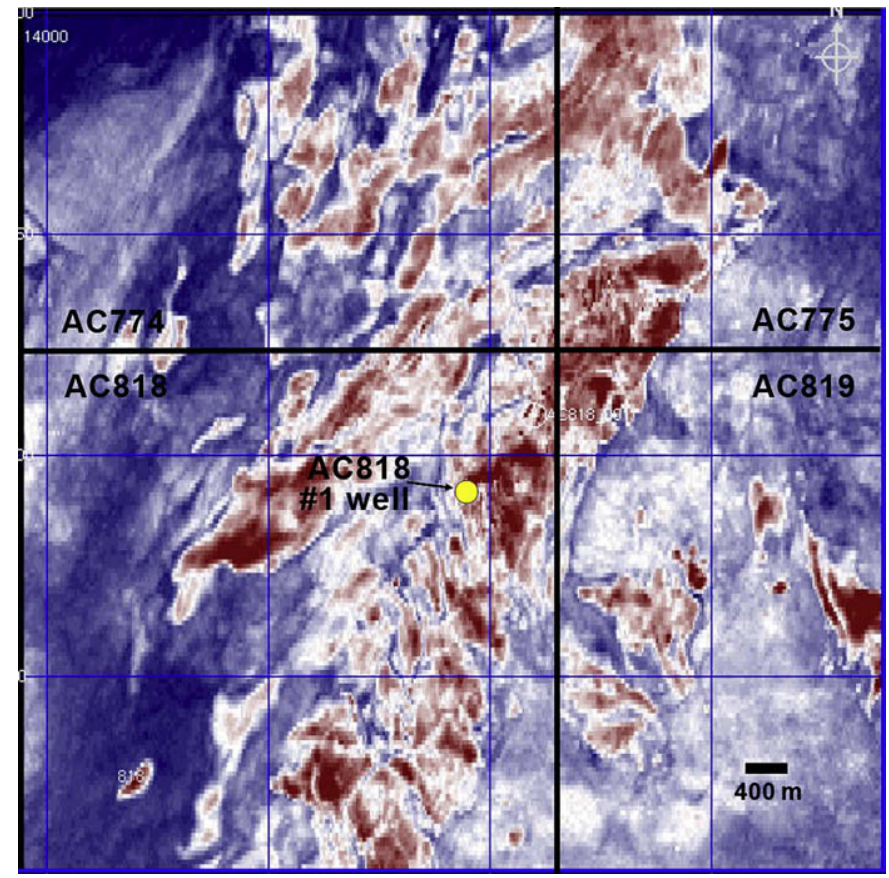

Fig. 11. Map of P-impedance within a $100 \mathrm{~ms}$ window below the interpreted BHSZ Low P-impedance values are indicated in red, and correspond to "bright spots" that indicate accumulations of free gas. (For interpretation of the references to colour in this figure legend, the reader is referred to the web version of this article.) 

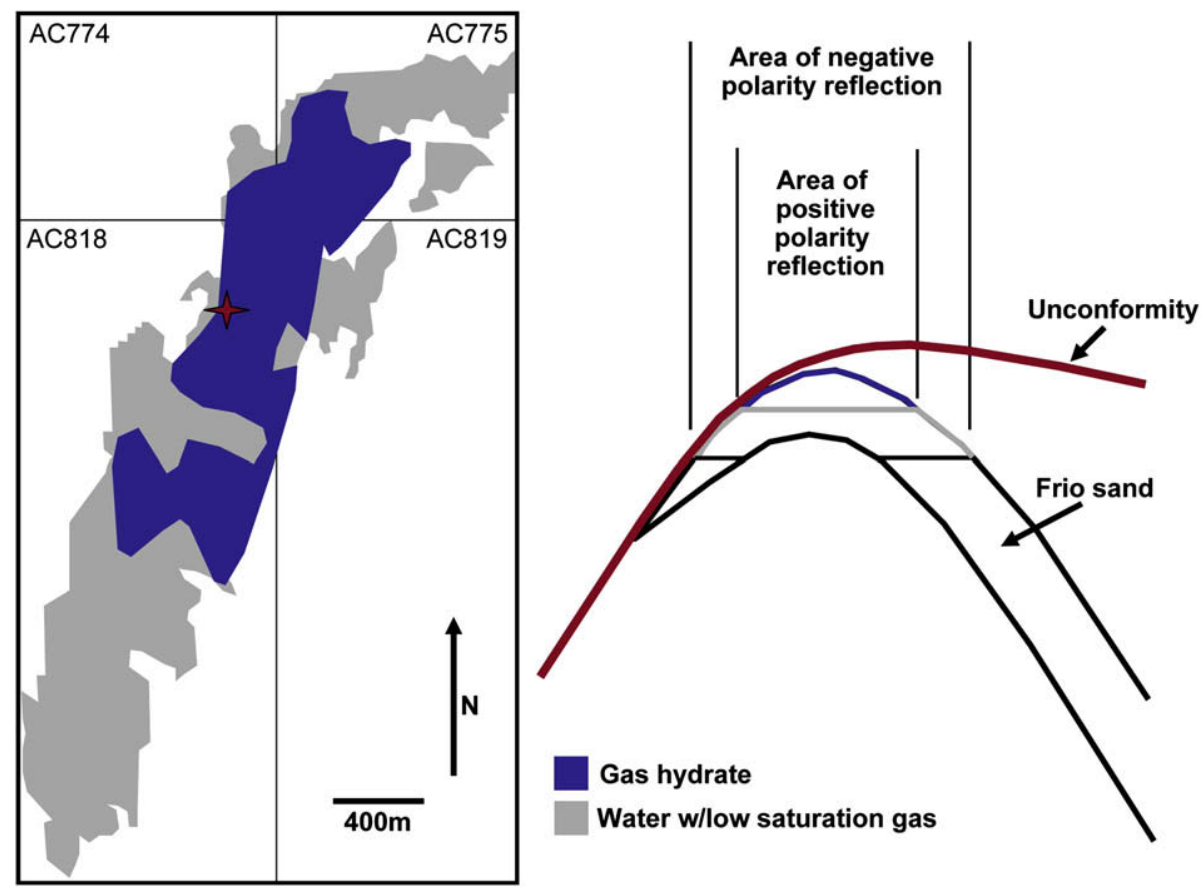

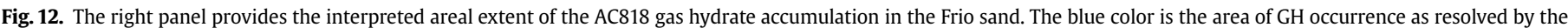

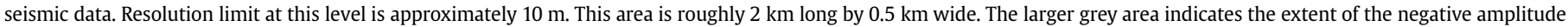

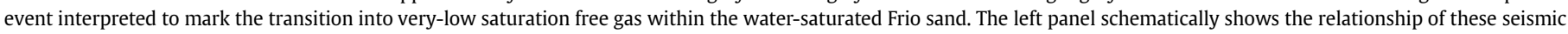

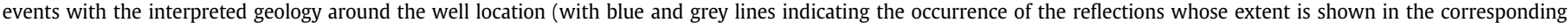

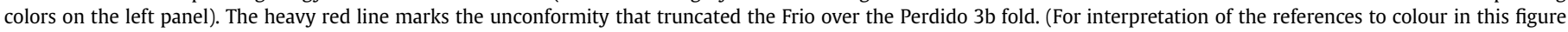
legend, the reader is referred to the web version of this article.)

\subsection{Summary of log-based estimations of gas hydrate saturation}

We have reported that resistivities and acoustic velocities within the upper $52 \mathrm{ft}(16 \mathrm{~m})$ of the Frio sand in the AC 818 well are significantly elevated above the values expected assuming the reservoir were fully saturated with connate waters. Our assumption is that these effects are due to the addition of gas hydrate to the sediment. Gas hydrate and ice are both potential pore-filling materials with intrinsically high velocity and resistivity, although ice cannot be present in this formation given its in situ temperature of roughly $20^{\circ} \mathrm{C}$. Therefore, our interpretation of the logging data confirms the presence of gas hydrate in two main zones: an upper $20 \mathrm{ft}(6 \mathrm{~m})$ interval with Sgh reaching 80\% (10 530-10 $550 \mathrm{ft})$, and a lower $22 \mathrm{ft}(7 \mathrm{~m})$ interval with Sgh just less than $80 \%$ (10 560-10 $582 \mathrm{ft}$ ). The sedimentological description obtained from sidewall core samples (Table 1 ) indicates that the intervening $3 \mathrm{~m}$
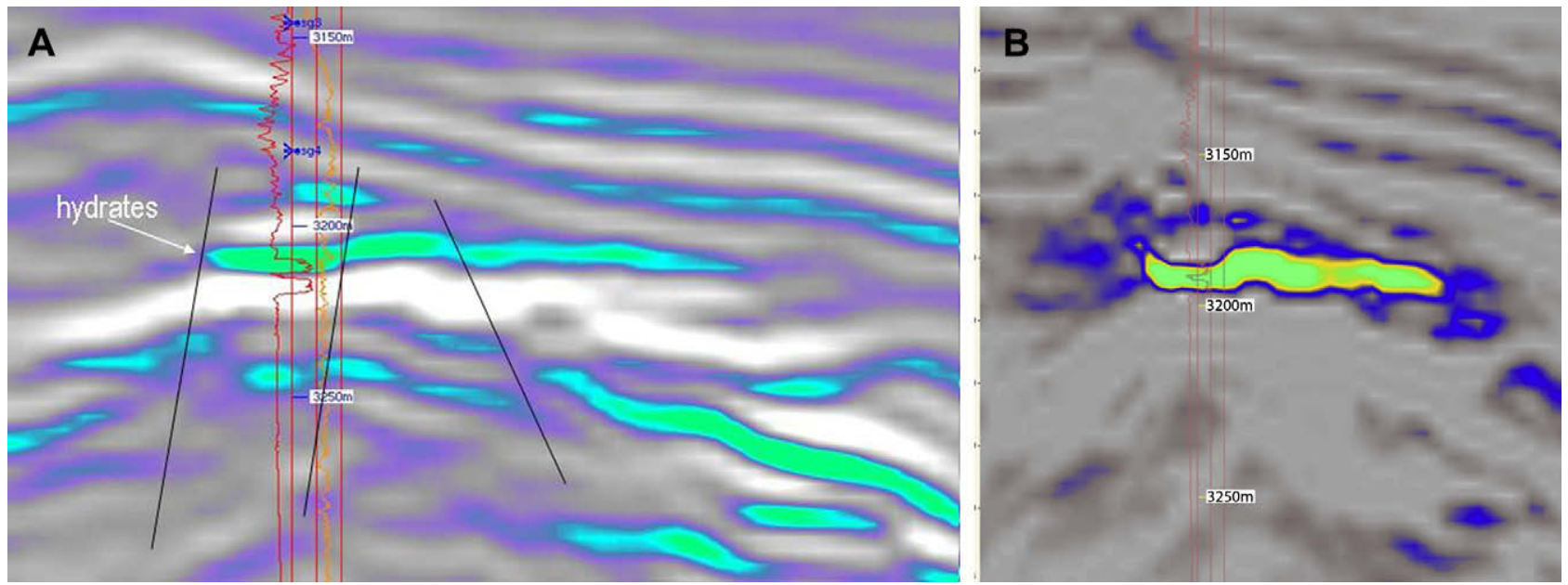

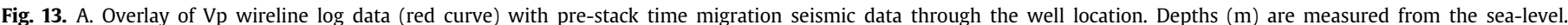

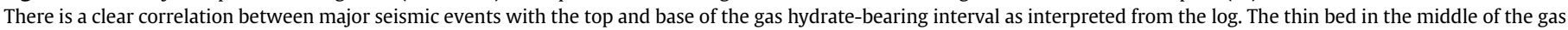

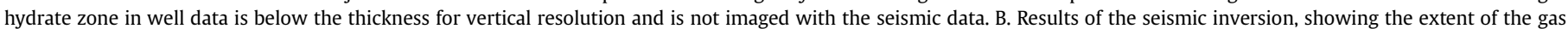

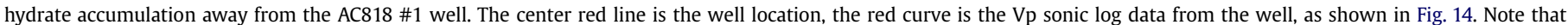

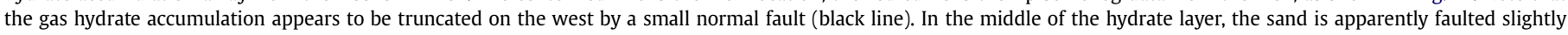
higher into the stability zone allowing a thicker accumulation of hydrates to occur. The vertical extent of the illustrated section is about $200 \mathrm{~m}$. 
zone of low gas hydrate saturation is marked by finer-grained sediments. The total thickness of the reservoir with gas hydrate saturation in excess of $70 \%$ is therefore approximately $42 \mathrm{ft}(13 \mathrm{~m})$.

\section{Seismic data interpretation}

The 3D seismic data over a $23 \mathrm{~km}^{2}$ area centered upon the AC818 \#1 well were reprocessed with the objectives of maximizing data resolution in the first kilometer of sediment below the seafloor. Curved ray Kirchhoff Pre-stack-time-migration processing was used to improve the imaging of the complex stratal geometries in the area and to provide correctly imaged pre-stack data for inversion and estimation of Sgh. The following describes the findings of the seismic data analysis.

\subsection{Reservoir description from regional seismic data}

Fig. 10 is a diagrammatic west-to-east cross-section depicting the primary geologic features in the vicinity of the AC818 \#1 well as revealed by the integration of the seismic data with log data acquired in the AC818 \#1 well. At the well location, and along much of the fold crest, the Frio sand is inferred to be partially eroded by a major unconformity. On the northwestern flank of the fold, this unconformity completely removes the Frio sands. The sand is believed to be fully present along the fold's southeast limb, however, there are no other well penetrations in the area, and the full original thickness of the Frio is not confidently known. In the vicinity of the well location, the Frio sand is overlain unconformably by predominantly fine-grained Plio-Pleistocene sediments. Additional unconformities are evident within this younger section.

The inference from the well data of a concentrated gas hydrate deposit presumes the existence of all the critical elements of a gas hydrate system, including sufficient gas and water charge, migration pathways, trap, seal, and reservoir. Additional confirmation of the gas charge in the area is provided by numerous gas-related features in the seismic data, including isolated stratal-bound bright spots consistent with concentrations of free gas in reservoir-quality sandstones and broad regions of attenuation of high frequency data (Fig. 11). The seismic data also indicate the existence of possible gas migration pathways into the reservoir, including migration upwards along the dipping Frio sand horizon, as well as numerous high-angle normal faults of small throw (typically less than $33 \mathrm{ft}(10 \mathrm{~m})$ ) along the fold axis that formed in response to extension during folding.

Although there is no regional BSR in southeastern Alaminos Canyon, the depth to the base of the stability zone can be estimated by reference to the aligned terminations of bright spots. Several such terminations can be seen in the area that correspond closely to the base of the gas hydrate-bearing interval in the well (see Fig. 10). As a result, we conclude that it is most likely that the base of the gas hydrate in the well at $10582 \mathrm{ft}(3226 \mathrm{~m}$ ) also marks the base of the GHSZ.

Analysis of 3-D seismic data enables the estimation of the vertical and lateral dimension of the AC818 gas hydrate accumulation away from the \#1 well. Correlation to well data suggests that both the top and the base of the gas-hydrate accumulation are directly imaged in the seismic data. Fig. 13A illustrates the correlation between the well $\log$ and seismic data. A high amplitude, positive event (bright green) corresponds directly with the top of the gas-hydrate accumulation, while a large negative amplitude event (white) marks the base (Fig. 13A).

The lower, negative polarity event can be traced across an area roughly $2 \mathrm{~km}$ long and $0.5 \mathrm{~km}$ wide (Fig. 12) that closely follows the axis of the Perdido $3 \mathrm{~b}$ fold. We interpret the area where this negative polarity reflector is coincident with the upper event to mark the base of the gas hydrate bearing interval within the Frio sand. Where this lower event extends beyond the area of the upper event, it is most likely derived from the top of the Frio sand, and is caused by the juxtaposition of low velocity Plio-Pleistocene sands above even lower-velocity Frio sands containing water and minor concentrations of free gas. The amplitude of this event diminishes as traced further away from the fold crest, presumably due to the disappearance of the free gas within the Frio sand.

The data have sufficient frequency content $(75 \mathrm{~Hz})$ at the depth of the Frio sand in the well to resolve the gas hydrate-bearing sand as thin as approximate $33 \mathrm{ft}(10 \mathrm{~m})$. Therefore, the upper, positive polarity event is interpreted to delineate the presence of gas hydrate occurrence in the Frio sand of $\sim 33 \mathrm{ft}(10 \mathrm{~m})$ thickness or greater. This area is roughly $0.8 \mathrm{~km}^{2}$ in size.

\subsection{Gas hydrate saturations from seismic inversion}

Variation in the amplitudes of both the upper and lower seismic events are used to predict Sgh away from the well location (Figs. 13 and 14). The inversion of Sgh from acoustic amplitude data begins with the detailed analysis of the seismic wavelet and generation of acoustic impedance and shear impedance volumes, which are in

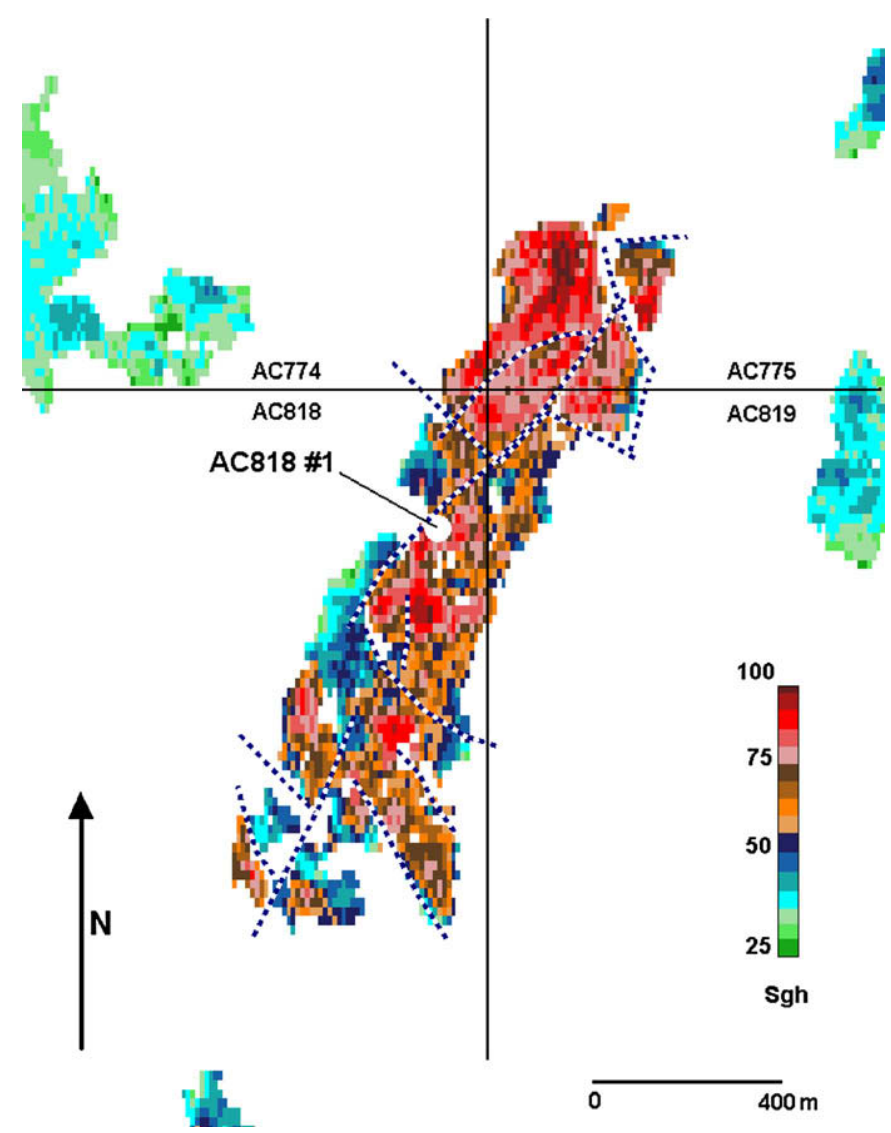

Fig. 14. Results of seismic inversion for gas hydrate saturation at the stratigraphic level of the AC818 \#1 gas hydrate accumulation. Detailed examination of the 3-D data reveal that the Frio sand corresponds to the areas of high saturation (orange and red colors). Areas of lower estimated gas hydrate saturation (blue shades) equate to seismic responses from units of Plio-Pleistocene age where those units replace the Frio at the base of the gas hydrate stability zone due to structural or stratigraphic features. Other anomalous areas shown in the map related to potential gas hydrate accumulations within other PlioPleistocene deposits (see Fig. 11) - such accumulations are expected to be within lowerquality reservoirs, consistent with the lower saturations shown. Dashed lines are normal faults of minor throw $(<10 \mathrm{~m})$ that potentially compartmentalize the accumulation. Larger faults have displaced the Frio sand outside the GHSZ, resulting in abrupt and linear terminations to the accumulation. (For interpretation of the references to colour in this figure legend, the reader is referred to the web version of this article.) 
turn, transformed into Sgh volumes (Xu et al., 2004; Dai et al., 2004; Dai et al, 2008). Carefully conditioned angle stacks were built as input for the simultaneous inversion (using ISIS ${ }^{\mathrm{TM}}$; an industryleading seismic inversion technology). Data acquired from the well were used for rock physics analyses using Bayesian statistical approaches. The model was then used to establish low frequency trends that exist below the seismic bandwidth, such as the trend of gradual increase in acoustic impedance with depth as sediments compact under increasing pressure. The model did not contain any gas hydrate-bearing layers, which allowed the higher frequency seismic data to independently drive the detection of gas hydrate anomalies wherever they occur since the seismic data responds to changes that occur over much smaller intervals. The amount of deviation observed between the predictions in the rock model and the actual seismic data was then transformed into a 3-D estimate of Sgh. The Sgh data shown here (Fig. 14) were derived from the compressional impedance volume.

Sgh on the structure is uniformly high and no areas of low or partially gas hydrate-saturated Frio sand in a position above the interpreted BGHS could be confidently identified. It appears that wherever the Frio sand occurs within the GHSZ, it is highly saturated with gas hydrate. Small-scale lateral variability in gas-hydrate saturation appears to be driven primarily by a network of minor normal faults (see Fig. 13 for examples). For example, the highest amplitudes occur to the north-northeast of the AC818 \#1 well within a fault block that has elevated a greater thickness of the Frio sand into the GHSZ. Similarly, areas adjacent to the anomaly, particularly on the west and the south of the accumulation, that are shown with lower estimated Sgh values are interpreted as areas where faulting has displaced the Frio reservoir below the BGHS (resulting in younger and low-quality reservoir being located at the BGHS). On the eastern edge of the accumulation, low saturation estimates from the inversion likely reflect the effects of thinning of the gas-hydrate-saturated portion of the Frio. In other words, even in these areas where low Sgh values are calculated from the inversion, we believe that the Frio is fully saturated with gas hydrate, but thinned below seismic resolution.

\section{Volumetrics}

The AC818 accumulation is interpreted to cover an area of 8.6 million $\mathrm{ft}^{2}\left(0.8 \mathrm{~km}^{2}\right)$. Using an average thickness of $59 \mathrm{ft}(18 \mathrm{~m})$, an average porosity of $42 \%$, and average Sgh of $80 \%$, we interpret approximately 170 million $\mathrm{ft}^{3}\left(4.8\right.$ million $\left.\mathrm{m}^{3}\right)$ of solid phase gas hydrate present. An average methane yield per unit of gas hydrate of 164 suggests a total in-place methane resource of 28 billion $\mathrm{ft}^{3}$ $\left(\sim 800\right.$ million $\left.\mathrm{m}^{3}\right)$.

\section{Numerical simulation of potential productivity}

The AC818 accumulation is currently one of the best characterized marine sandstone gas hydrate reservoirs, affording the opportunity to assess the potential of the accumulation for wellbased extraction of natural gas. To provide a first-order estimate of the potential response of an accumulation of this type to wellbased production, numerical simulations were conducted using the parallelized version of the Tough + /HYDRATE code.

For these simulations, reservoir properties were assigned consistent with the $\log$ and seismically-derived characterization described above (porosity of $42 \%$ and intrinsic permeability of 1 Darcy) and are assumed to be uniform throughout the total area. The deposit is idealized as uniformly $(48 \mathrm{~m})$ in thickness and elliptical in shape, extending roughly $(500 \mathrm{~m})$ from east-to-west and $(1200 \mathrm{~m})$ from north-to-south. The upper $(18 \mathrm{~m})$ of the sand has $75 \%$ of pore space occupied with gas hydrate; the lower $(30 \mathrm{~m})$ is fully water saturated. The Frio sand is modeled as bounded
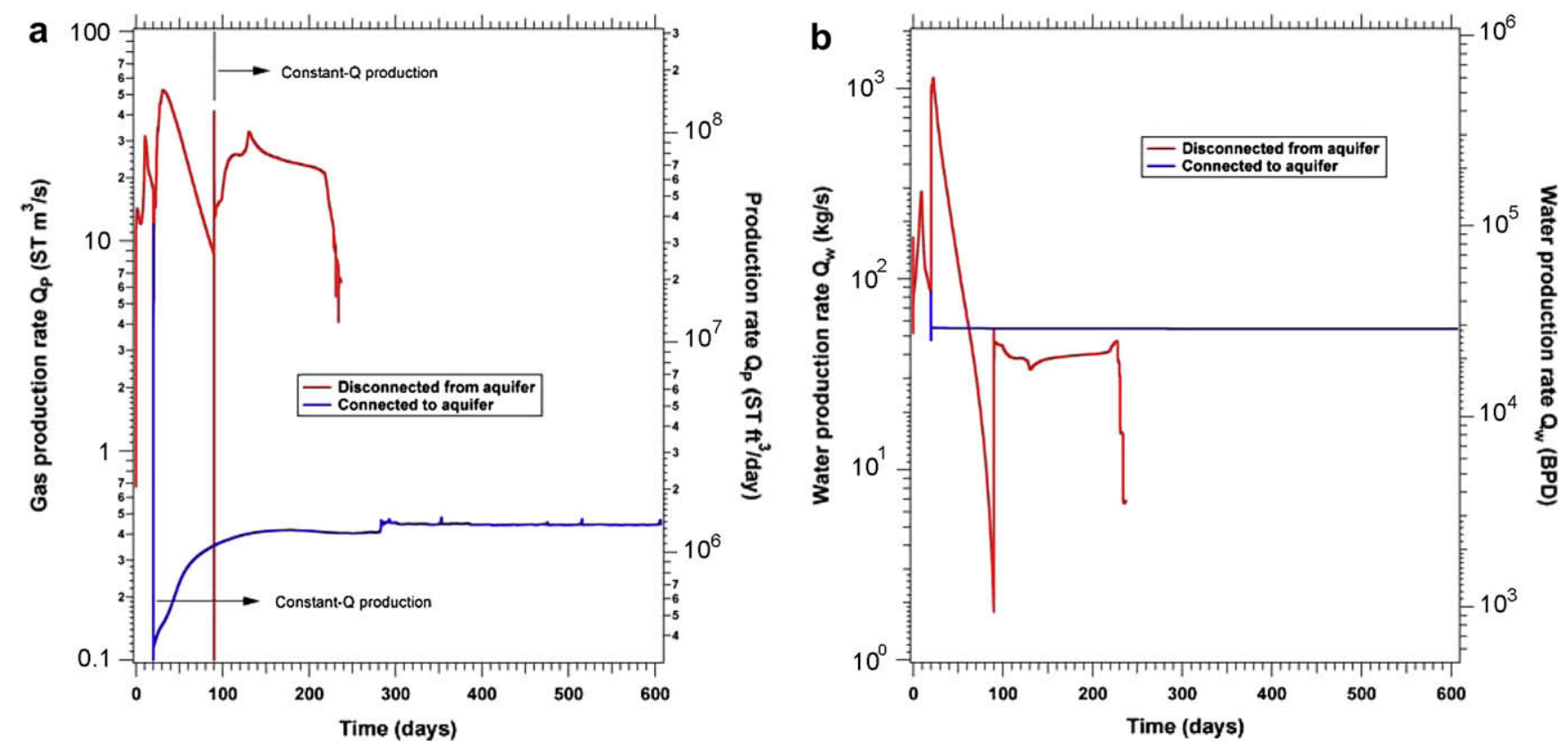

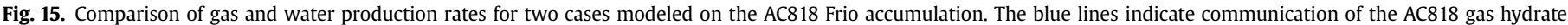

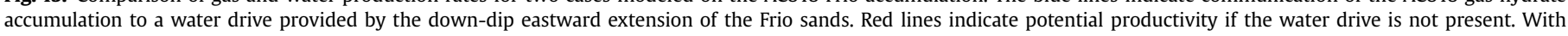

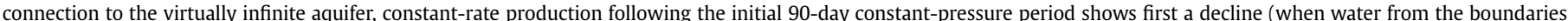

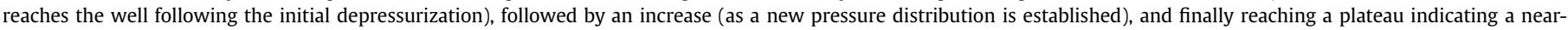

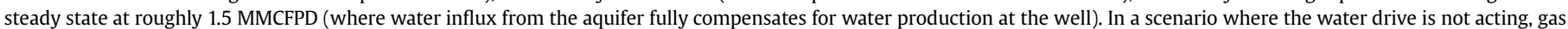

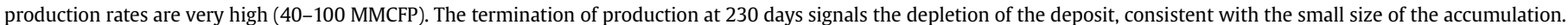

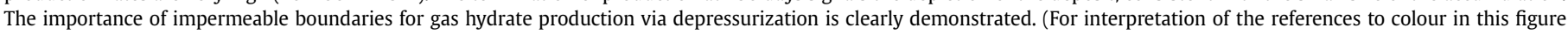
legend, the reader is referred to the web version of this article.) 
by impermeable shales above and below. In addition, the upper $(18 \mathrm{~m})$ gas hydrate-bearing zone is also bounded laterally with impermeable shale formations that can exchange heat with the surroundings. In contrast, the lower $(30-\mathrm{m})$ water-bearing zone is bounded laterally only to the west and to the north; the southern and eastern boundaries were assumed to extend an additional $(50 \mathrm{~m})$ beyond the western edge of the gas hydrate-bearing zone, at which point they were assumed to be connected to an infinite aquifer. The initial pressure distribution was assumed as hydrostatic. Temperature was based on the assumption that the bottom of the hydrate stability zone is coincident with the base of the gas-hydrate bearing zone. The approach used in the initialization and execution of this study follows that discussed in earlier reported simulations (see Moridis and Reagan, 2007a,b). Modeling employed a three-dimensional grid with almost 600000 cells, and required the solution of about 2.4 million simultaneous equations.

The production strategy simulated is depressurization-induced dissociation through fluid removal. We used a single horizontal well with a length of $1100 \mathrm{~m}$ that was located about $50 \mathrm{~m}$ from the eastern boundary of the idealized elliptical formation. The reason for this placement was an attempt to exploit the proximity of impermeable shale boundaries provided by the erosional truncation of the Frio sand. In addition, the well was placed at the top of the sand to take advantage of the gas accumulating near the top of the formation during dissociation, and to avoid as much as possible the drainage of the water released from dissociation.

Because of the very low initial effective permeability of the formation, it was not possible to produce (initially) at a constant rate. Thus, an initial stage of constant-pressure production, with the well kept at a pressure $\left(\mathrm{P}_{\mathrm{w}}\right)$ of $30 \mathrm{MPa}$ was extended to 90 days in an attempt to aggressively produce from the deposit and obtain an estimate of its response under a worst-case scenario (as the aggressive depressurization and the short time frame reduced the conduction-dominated heat influx into the deposit). Production then switched to a constant-rate mode, with water withdrawal set at 30000 barrels per day.

Following the initial constant-P period, degree of hydrate dissociation and associated gas production rates are very low (blue
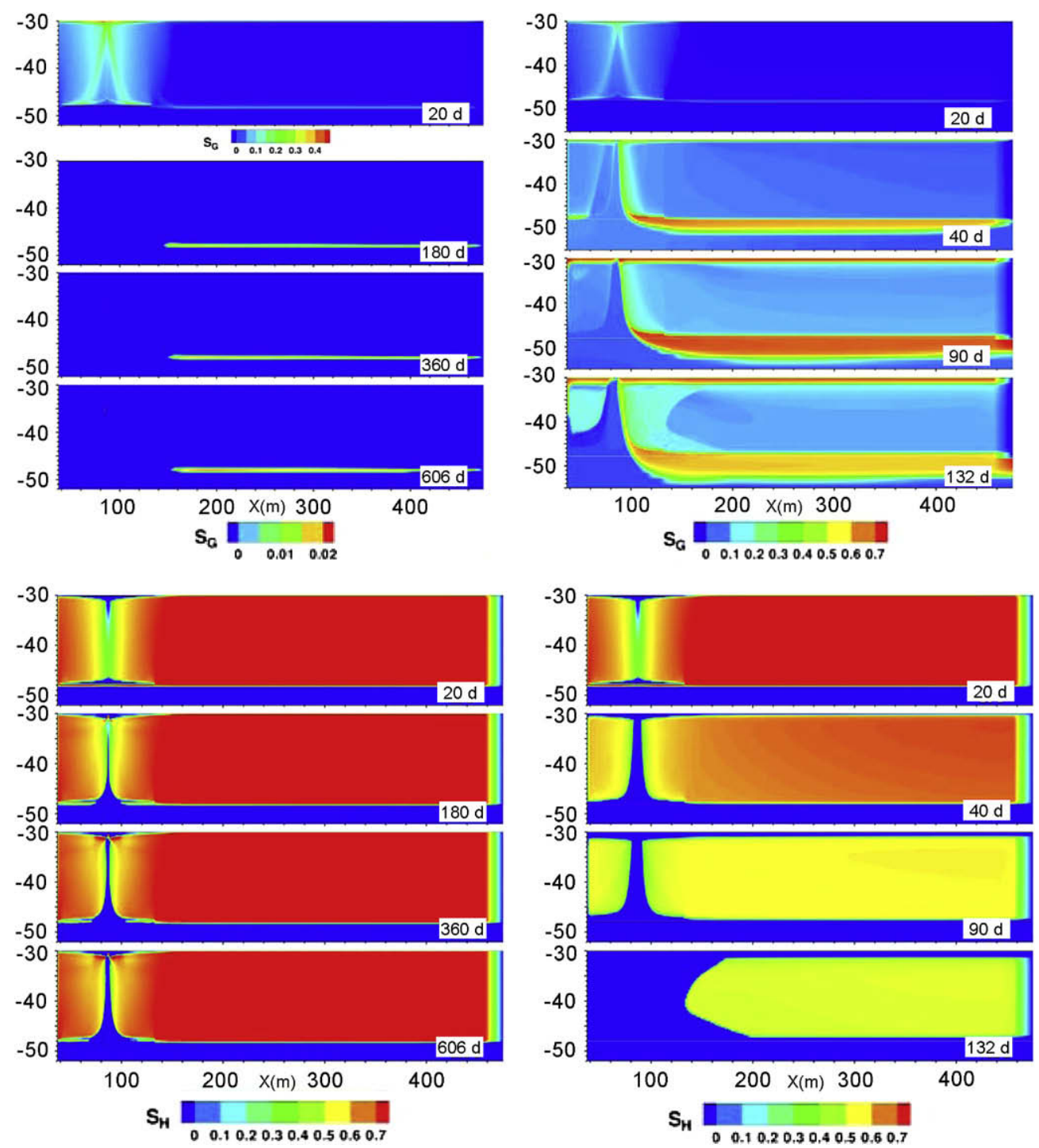

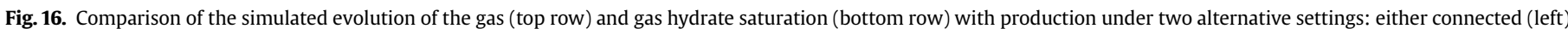

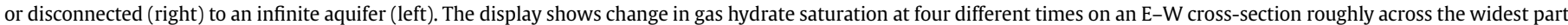

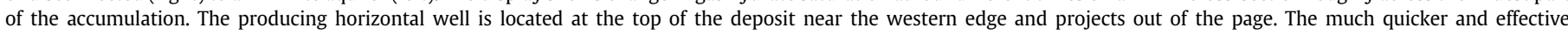
destruction of the gas hydrate in the case with no aquifer connection is readily apparent. 
line on Fig. 15a). Clearly, this behavior is caused by the deposit being in direct communication with the infinite aquifer. This setting, when coupled with the high permeability of the system, does not allow effective depressurization. The limited depressurization does not allow significant gas release and accumulation, while the inexhaustible supply of water from the Frio to the east and south floods the system and allows only a small band of free gas to exist near the dissociating interface.

To explore the effect of the water drive further, an alternative case was conducted in which the infinite aquifer (50 $\mathrm{m}$ to the east of the edge of the gas hydrate accumulation) was replaced with an impermeable boundary. As expected, the results are drastically different, with productivity enhanced by almost 2 orders of magnitude (rates ranging between 40 and 100 million $\mathrm{ft}^{3}$ (1.1 and 2.8 million $\mathrm{m}^{3}$ ) per day) and water production rates steady at 30000 barrels $\left(3520 \mathrm{~m}^{3}\right.$ ) per day (Fig. 16). This finding clearly highlights the strong advantages of having a closed system (unconnected to extensive aquifers) when attempting to produce from hydrate deposits by means of depressurization and the substantial productivity that can be achieved in gas hydrate reservoirs in certain settings. Further comparison of the two cases is provided in Fig. 16. Of course, due to the lack of data on such formations, additional field studies and numerical simulations are necessary before firm conclusions can be reached as to the production potential of natural hydrates.

\section{Summary}

In 2005, the first known full log suite across a portion of the gas hydrate stability zone in the northern Gulf of Mexico was acquired in the AC block 818 \#1 (“Tigershark”) well. The logging program was designed to determine the nature of the sediments and pore fill associated with a very strong negative seismic amplitude anomaly observed at the expected depth of both the Oligocene Frio sands and the BGHS. These logging data, along with reprocessed 3-D seismic data, indicate the presence of a $42 \mathrm{ft}(13 \mathrm{~m})$ thick occurrence of high-saturation, pore-filling gas hydrate within a sand reservoir.

Gas hydrate is interpreted to occur where the Frio Sand is uplifted into the gas hydrate stability zone along the crest of fold $3 \mathrm{a}$ of the Perdido Fold belt in the vicinity of the AC818 \#1 well. Gas hydrate saturations, as inferred from analysis of both resistivity and acoustic data, are uniformly high at the well location, typically exceeding $70 \%$, with maximum values of roughly $80 \%$. It is assumed that the gas hydrate-water contact observed in the well marks the BGHS.

Analysis of the 3-D seismic data indicates ample evidence of gas charge throughout the area of the well. Lithologic samples obtained from the well revealed the Frio to be a high-porosity, high permeability volcanoclastic sand. Well-log derived porosity averages $42 \%$ and intrinsic (non-gashydrate-bearing) permeability is typically 1 Darcy or more, making the Frio a high-quality reservoir rock. Gas migration into the accumulation could have occurred along numerous near-vertical faults imaged within the accumulation (with throws of $10 \mathrm{~m}$ or more) or up the permeable Frio pathway along the western edge of the fold. The trap for the accumulation is created by four-way fold closure related to the compressional tectonism of the Perdido fold belt. The reservoir seal is provided by finegrained Pleistocene muds that lie above an angular unconformity that partially removes the Frio sand along the fold crest and fully removes the sand along the fold's eastern limb. Maximum thickness of the reservoir is roughly $100 \mathrm{ft}(30 \mathrm{~m})$ and occurs along the fold crest near the northeast corner of Alaminos Canyon block 818.

Both the top and the base of the hydrate-bearing interval are directly imaged in the seismic data and can be mapped throughout an area of roughly 8.6 million $\mathrm{ft}^{2}\left(0.8 \mathrm{~km}^{2}\right)$. Inversion of amplitude data based on calibration with log data from the AC818 \#1 well reveals that gas hydrate saturation remains uniformly high wherever the Frio reservoir lies above the base of gas hydrate stability. In no areas does the Frio appear to contain less than $60-65 \%$ gas hydrate saturation where it occurs above the interpreted BGHS. Common saturation values interpreted throughout the accumulation are $80 \%$ or higher. Total methane gas resource present within the accumulation is estimated at slightly more than 28 billion $\mathrm{ft}^{3}\left(\sim 800\right.$ million $\left.\mathrm{m}^{3}\right)$.

Numerical modeling of the potential productivity of the Frio reservoir indicates that the potential for a strong water drive in this particular setting renders effective reservoir depressurization impossible, leading to low gas flow rates.

\section{Acknowledgments}

The authors wish to thank Chevron North America Exploration and Production Company and Schlumberger Reservoir Services for access to data. This work was also partially supported by the U.S. Department of Energy under Contract No. DE-AC0205CH11231. An earlier version of this paper benefited greatly from review by Dr. Carolyn Ruppel.

\section{References}

Castagna, J., Batzle, M., Eastwood, R., 1985. Relationship between compressionalwave and shear-wave velocities in clastic silicate rocks. Geophysics 50, 571-581.

Claypool, G., 2006. Cruise Report: the Gulf of Mexico Gas Hydrate Joint Industry Project, Covering the Cruise of the Drilling Vessel Uncle John, Mobile, Alabama to Galveston, Texas; Atwater Valley blocks 13/14 and Keathley Canyon block 151, 17 April to 22 May 2005. http://www.netl.doe.gov/technologies/oil-gas/ 
publications/Hydrates/reports/GOMJIPCruise05.pdf.

Collett, T., Ladd, J., 2000. Detection of gas hydrate with downhole logs and assessment of gas hydrate concentrations (saturations) and gas volumes on the Blake Ridge with electrical resistivity log data. In: Paull, C.K., Matsumoto, R., Wallace, P.J., Dillon, W.P. (Eds.), Proceedings of the Ocean Drilling Program, Scientific Results, vol. 164, pp. 179-191. College Station, TX.

Cook, A., Goldberg, D., Kleinberg, R., 2008. Fracture-controlled gas hydrate systems in the Gulf of Mexico. Marine and Petroleum Geology 25 (9), 932-941.

Cooper, A., Hart, P., 2003. High-resolution seismicreflection investigation of the northern Gulf of Mexico gas-hydrate-stability zone. Marine and Petroleum Geology 19, 1275-1293.

Cordes, E., Carney, S., Hourdez, S., Carney, R., Brooks, J., Fisher, C., 2007. Cold seeps of the deep Gulf of Mexico: community structure and biogeographic comparisons to Atlantic equatorial belt seep communities. Deep Sea Research Part 1: Oceanographic Research Papers 54 (4), 637653.

Dai, J., Xu, H., Snyder, F., Dutta, N., 2004. Detection and estimation of gas hydrates using rock physics and seismic inversion: examples from the northern deepwater Gulf of Mexico. The Leading Edge 23, 60-66.

Dai, J., Banik, N., Gillespie, D., Dutta, N., 2008. Exploration for gas hydrates in the Deepwater Northern Gulf of Mexico: model validation by drilling. Marine and Petroleum Geology 25 (9), 845-859.

Fiduk, J., Weimer, P., Trudgill, B., Rowan, M., Gale, P., Phair, R., Korn, B., Roberts, G., Gafford, W., Lowe, R., Queffelec, T., 1999. The Perdido Fold Belt, northwestern Gulf of Mexico, part 2: seismic stratigraphy and petroleum systems. AAPG Bulletin 83 (4), 578-612.

Fujii, T., Nakamizu, M., Tsuji, Y., Okui, T., Kawasaki, M., Ochiai, K., 2005. Modes of occurrence and accumulation mechanism of methane hydrate - result of METI exploration test wells "Tokai-oki to Kumano-nada". Proceedings of the Fifth International Conference on Gas Hydrates, ICGH2005 paper 3041, 974-979.

Guerin, G., Goldberg, D., 2002. Sonic waveform attenuation in gas hydrate bearing sediments from the Mallik 2L-38 research well, Mackenzie Delta, Canada. Journal of Geophysical Research 107 (B5), doi:10.1029/2001JB000556.

Hart, P., Hutchinson, D., Gardner, J., Carney, R., Fornari, D., 2008. A photographic and acoustic transect across two deep-water seafloor mounds, Mississippi Canyon, northern Gulf of Mexico. Marine and Petroleum Geology 25 (9), 969-976.
Hutchinson, D., Hart, P., Ruppel, C., Snyder, F., Dugan, B. Seismic and thermal characterization of a bottom simulating reflection in the northern Gulf of Mexico. In Collett, T., Johnson, A., Knapp, C., Boswell, R. (Eds.), Natural Gas Hydrates: Energy Resources, Potential and Associated Geologic Hazards, AAPG Memoir 89, in press-a.

Hutchinson, D., Hart, P., Collett, T., Edwards, K., Twichell, D., Snyder, F., 2008. Geologic framework of the Keathley Canyon gas hydrate research well, northern Gulf of Mexico. Marine and Petroleum Geology 25 (9), 906-918.

Kvenvolden, K., 2000. Gas hydrate and humans. In: Holder, G., Bishnoi, P. (Eds.), Gas Hydrates: Challenges for the Future, vol. 912. Annals of the New York Academy of Sciences, pp. 17-22.

Kvenvolden, K., Lorenson, T., 2001. The global occurrence of gas hydrate. In: Paull, C., Dillon,W. (Eds.), Natural Gas Hydrates: Occurrence, Distribution, and Detection. Geophysical Monograph, vol. 124. American Geophysical Union, pp. 3-18.

Lee, M., 2002. Biot-Gassmann theory for velocities of gas hydrate-bearing sediments. Geophysics 67, 1711-1719.

Lee, M., 2005. Well Log Analysis to Assist the Interpretation of 3-D Seismic Data at Milne Point, North Slope of Alaska. U.S. Geological Survey Scientific Investigation. http://pubs.usgs.gov/sir/2005/5048, Report 20055048, 18 pp.

Lee, M., Collett, T., 2008. Integrated analysis of well logs and seismic data to estimate gas hydrate concentrations at Keathley Canyon, northern Gulf of Mexico. Marine and Petroleum Geology 25 (9), 924-931.

MacDonald, I., Guinasso, N., Sassen, R., Brooks, J., Lee, L., Scott, K., 1994. Gas hydrate that breaches the sea floor on the continental slope of the Gulf of Mexico. Geology 22, 699-702.

McConnell, D., Kendall, B., 2002. Images of the Base of Gas Hydrate Stability, Northwest Walker Ridge, Gulf of Mexico. Society of Petroleum Engineers. Offshore Technology Conference paper \#14103.

Meyer, D., Zarra, L., Rains, D., Meltz, B., Hall, T., May 2005. Emergence of the lower Tertiary Wilcox trend in the deepwater Gulf of Mexico. World Oil, 72-77.

Milkov, A., Sassen, R., 2001. Estimate of gas hydrate resource, northwestern Gulf of Mexico continental slope. Marine Geology 179, 71-83.

Moridis, G., Reagan, M., 2007a. Gas Production from Oceanic Class 2 Hydrate Accumulations. Society of Petroleum Engineers. Offshore Technology Conference, paper \#18866.

Moridis, G., Reagan, M., 2007b. Strategies for Gas Production from Oceanic Class 3 Hydrate 
Accumulations. Society of Petroleum Engineers. Offshore Technology Conference, paper \#18865.

Moridis, G., Sloan, D., 2007. Gas production potential of disperse low-saturation hydrate accumulations in oceanic sediments. Journal of Energy Conversion and Management 48 (6), 1834-1849.

Paull, C., Ussler, W., Lorenson, T., Winters, W., Dougherty, J., 2005. Geochemical constraints on the distribution of gas hydrates in the Gulf of Mexico. Geo-Marine Letters 25, doi:10.1007/s00367-005-0001-3.

Reidel, M., Collett, T., Malone, M., Expedition 311 Scientists, 2006. Proceedings IODP, vol. 311, doi:10.2204/iodp.proc.311.2006 Washington, DC.

Roberts, H., Carney, R., 1997. Evidence of episodic fluid, gas, and sediment venting on the northern Gulf of Mexico continental slope. Economic Geology 92, 863-879.

Roberts, H., Fisher, C., Brooks, J., Bernard, B., Carney, R., Cordes, E., Shedd, W., Hunt, J., Joye, S., MacDonald, I., Morrison, C., 2007. Exploration of the Deep Gulf of Mexico Slope Using DSV Alvin: Site Selection and Geologic Character. Gulf Coast Association of Geological Societies.

http://www.gcags2007.com/abstracts/roberts.et.a l.pdf abstracts.

Ruppel, C., Dickens, G., Castellini, D., Gilhooly, W., Lizzarralde, D., 2005. Heat and Salt Inhibition of Gas Hydrate Formation in the Northern Gulf of Mexico. Geophysical Research Letters 32 (4), L04605, doi:10.1029/2004GL021909.

Ruppel, C., Boswell, R., Jones, E., 2008. Scientific results of 2005 US DOE-Chevron JIP drilling for methane hydrates objectives in the Gulf of Mexico: introduction and overview. Marine and Petroleum Geology 25 (9), 819-829.

Shafer, J., Chen, S., Georgi, D., 2005. Protocols for Calibrating NMR Log Derived Permeabilities. Proceedings, International Society of Core Analysts, Toronto Canada. http://www.scaweb.org/assets/papers/2005_pape rs/1-SCA2005-37.pdf.

Shipley, S., Sarna-Wojcicki, A., 1982. Distribution, thickness, and mass of late Pleistocene and Holocene tephra from major volcanoes in northwestern United States: a preliminary assessment of hazards from volcanic ejecta to nuclear reactors in the Pacific Northwest. U.S. Geological Survey Miscellaneous Field Studies Map MF-1435.

Smith, M., Kou, W., Ahmed, A., Kuzela, R., 2005. The Significance of Gas Hydrate as a Geohazard in Gulf of Mexico Exploration and Production. Society of Petroleum Engineers. Offshore Technology Conference, paper \#17655.

Smith, S., Boswell, R., Collett, T., Lee, M., Jones, E., 2006. Alaminos Canyon Block 818: a
Documented Example of Gas Hydrate Saturated Sand in the Gulf of Mexico. Fire in the Ice, the U.S. DOE/NETL Methane Hydrates Newsletter: Fall 2006.

http://www.netl.doe.gov/technologies/oilgas/publications/Hydrates/Newsletter/ HMNewsFall06.pdf, pp. 12-13.

Trudgill, B., Rowan, M., Fiduk, J., Weimer, P., Gale, P., Korn, B., Phair, R., Gafford, W., Roberts, G., Dobbs, S., 1999. The Perdido Fold Belt, northwestern Gulf of Mexico, Part 1: structural geology, evolution, and regional implications. AAPG Bulletin 83 (1), 88-113.

Tsuji, Y., Hisashi, I., Masaru, N., Matsumoto, R., Shimizu, S., 2004. Overview of the MITI Nankai Trough Wells. A milestone in the evaluation of methane hydrate resources. Resource Geology 54, 3-10.

Vanneste, M., De Batist, M., Golmshtok, A., Kremlev, A., Versteeg, W., 2001. Multifrequency seismic study of gas hydratebearing sediments in Lake Baikal, Siberia. Marine Geology 172, 1-21.

Wood, W., Hart, P., Hutchinson, D., Dutta, N., Snyder, F., Coffin, R., Gettrust, J., 2008. Gas and gas hydrate distribution around seafloor seeps in Mississippi Canyon, northern Gulf of Mexico, using multi-resolution seismic Imagery. Marine and Petroleum Geology 25 (9), 952-959.

Xu, H., Dai, J., Snyder, F., Dutta, N., 2004. Seismic detection and quantification of gas hydrates using rock physics and inversion. In: Taylor, C., Kwan, J. (Eds.), Advances in the Study of Gas Hydrates. Kluwer, New York, pp. 117-139. 